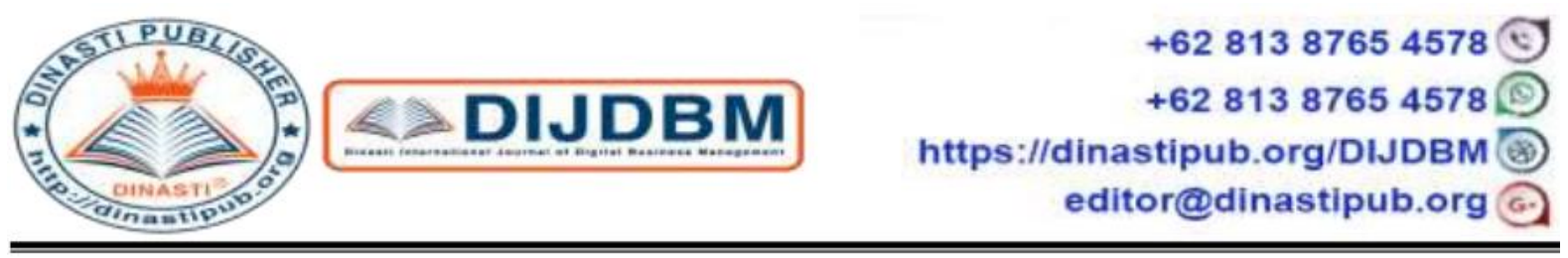

\title{
THE EFFECT OF WORKLOAD AND JOB CHARACTERISTICS ON EMPLOYEE PERFORMANCE THROUGH WORK-SCHOOL CONFLICT AS MEDIATION VARIABLE
}

Ade Setyowati $^{1)}$ Mafizatun Nurhayati $\left.^{2}\right)$

${ }^{1,2}$ Master of Management, Universitas Mercu Buana, Jakarta, Indonesia

\begin{tabular}{|c|c|}
\hline $\begin{array}{l}\text { ARTICLE INFORMATION } \\
\text { Received : January } 15^{\text {th }} 2020 \\
\text { Revised : January } 20^{\text {th }} 2020 \\
\text { Issued : January } 25^{\text {th }} 2020 \\
\text { Corresponding author: } \\
\text { Ade Setyowati } \\
\text { E-mail: } \\
\text { adesetyowati05@gmail.com, } \\
\text { mafizatun.nurhayati@mercubuana.ac.id }\end{array}$ & $\begin{array}{l}\text { Abstract: This study aims to examine and analyze } \\
\text { the effect workload and job characteristics on } \\
\text { employee performance through work-school } \\
\text { conflict as a mediating variable for employees who } \\
\text { are continuing their graduate studies. The research } \\
\text { method uses quantitative approaches. The sample } \\
\text { selection is done by using Hair Methodl, namely by } \\
\text { multiplying 5-15 with indicators ( } 60 \text { indicators), so } \\
\text { sample obtained by } 300 \text { employees who are } \\
\text { continuing their graduate studies in Jakarta. The } \\
\text { technique of collecting data uses a questionnaire. } \\
\text { Data were analyzed using SEM-PLS } 3.0 \text {.The result } \\
\text { showed that wokload had a positive and significant } \\
\text { effect on work-school conflict, but no effect on } \\
\text { employee performance. Job characteristics had a } \\
\text { positive and significant effect on employee } \\
\text { performance, but no effect on work-school conflict. } \\
\text { Work-school conflict had negative and significant } \\
\text { effect on employee performance. In addition, work- } \\
\text { school conflict had full mediated work load on } \\
\text { employee performance, but no effect mediating for } \\
\text { characteristics to employee performance } \\
\text { Keywords: workload, job characteristics, work- } \\
\text { school conflict, employee performance }\end{array}$ \\
\hline
\end{tabular}

\section{INTRODUCTION}

The company's success in achieving the vision, mission, and targets set by the company is an accumulation of the successful implementation of the main tasks and functions of each employee in it. Thus, individual employee performance is one of the factors that can determine overall organizational performance. Irawati and Carollina (2017) state that employee performance is the result of employee performance in the form of inputs or outputs, it also can be called the results of quantity and quality of work to achieve the targets set by the company so that performance in the company can achieve successfull. Performance appraisals are 
conducted to provide feedback to employees who aim to improve the employee and organizational performance.

Based on the pre-survey conducted to 30 respondents conducted to graduate students who were employees, the following results were obtained:

Table 1. Presurvey of graduate students who were permanent employees

\begin{tabular}{lcc}
\hline Questions & Yes & No \\
\hline I feel less than optimal in my performance & $53 \%$ & $47 \%$ \\
\hline I feel that I haven't worked hard for the company & $66 \%$ & $34 \%$ \\
\hline
\end{tabular}

Source: Processed Data (2019)

Based on Table 1. it can be seen that $53 \%$ of respondents feel they are not optimal in their performance and $66 \%$ of respondents feel they have not worked hard for the company. This is contrary to the companies expectations that want constant and even improved employee performance.

The high costs that have to be spent to continue their graduate program, make them choose to work and study at the same time. Table 2 shows an increase in the number of Indonesians who continued their studies in this 3 years.

Table 2. Data Of Graduate Students in Indonesia

\begin{tabular}{cccc}
\hline \multirow{2}{*}{ Year } & \multicolumn{3}{c}{ Number of Student in Indonesia } \\
\cline { 2 - 4 } & $\begin{array}{c}\text { Undergraduat } \\
\text { e }\end{array}$ & Graduate & Doctor \\
\hline $2014 / 2015$ & 47,2 & 90 & 41,5 \\
\hline $2015 / 2016$ & 46,8 & 106,3 & 119,9 \\
\hline $2016 / 2017$ & 41,5 & 119,9 & 21,8 \\
\hline urce: Antara, Pangkalan Data pendidikan Tinggi, Kemenristek-Dikti
\end{tabular}

The researcher then conducted a second survey to graduate students about the reasons for continuing graduate study and choosing to study while working. PraSurvey was filled by 30 respondents from Universities in the Jakarta area that were Accredited A with the following results:

Table 3. Prasurvey The Reasons for Continuing Graduate Studies

\begin{tabular}{clcc}
\hline No & \multicolumn{1}{c}{ Questions } & Information & $\begin{array}{c}\text { Percentag } \\
\mathbf{e}\end{array}$ \\
\hline \multirow{2}{*}{1} & $\begin{array}{l}\text { Reason for Continuing graduate } \\
\text { study }\end{array}$ & Career improvement & $60 \%$ \\
\cline { 2 - 4 } & $\begin{array}{l}\text { Expenses incurred while } \\
\text { undergoing roles as students and } \\
\text { employees }\end{array}$ & Add knowledge & $40 \%$ \\
\cline { 2 - 3 } 2 & Fee & $77 \%$ \\
\hline
\end{tabular}




\section{Source: Processed data}

Based on Prasurvey's results above, it can be seen that one of the reasons for continuing graduate study is to improve a better career. In government agencies, a Civil Servants (PNS) who will continue their studies will pass the diploma equalization that can be used to get a promotion. In addition, the benefits of continuing graduate studies are raise salary, increased job satisfaction, improvements in negotiations, time management, and leadership skills (Wyland, Lester, Mone, \& Winkel, 2013).

The emergence of problems that occur due to dual role conflict (between employees and students) is known as work-school conflict. refers to situations in which students experience work as reducing their ability, energy, and time to meet college demands (Park \& Sprung, 2013). The result of Warokka and Ferbilia (2015) research is WSC have no effect on employee performance. Instead of Jackon and Arianto (2017), Wyland (2013), Pertiwi Tanihaha (2016), and Burhanuddin (2018) said that the WSC had negative dan significant effect on employee performance.

Workload is one of the factors that can affect employee performance (Irawati \& Carollina, 2017). High workload implies that an employee must complete a number of jobs in a short time (Andrade, 2018). Research by Rolos, et al (2018) results that workloads have a negative and significant effect on employee performance, so increasing workload will reduce employee performance.

Research by Affandy (2016), Frismandiri (2007), and Djati (2003) result that job characteristics have positive and significant effect on employee performance. In addition there is a positive and significant relationship between work characteristics of work-family conflict (Carvalho \& Chambel (2017). Work-family conflict becomes one of the references in developing research, taking into consideration the similarity in role conflict.

Based on the background above, this research focuses on the problem formulation:

1. Does workload affect employee performance

2. Does job characteristics affect employee performance

3. Does workload affect work-school conflict

4. Does job characteristics affect work-school conflict

5. Does work-school conflict affect employee performance

6. Does workload affect employee performance through work-school conflict

7. Does job characteristics affect employee performance through work-school conflict

\section{LITERATURE REVIEW}

\section{A. Employee Performance}

Employee performance is the result of employee's work in the form of input or output and can also be called work results in quantity and quality to achieve the targets set by the company, so that company can achieve success (Irawati and Carollina, 2017). Employee performance can be measured by 5 dimensions, namely quality of work, quantity of work, punctuality, effectiveness, and independence.

\section{B. Work-School Conflict}

Work-school conflict refers to situations in which students experience work as reducing their ability, energy, and time to meet college demands (Park \& Sprung, 2013). Work-school conflict can be measured by 3 dimensions, namely time-based conflict, strain-based conflict, and behavior-based conflict. 


\section{Workload}

According to Irawati and Carolline (2018) workload is a set of activities that must be completed by an organizational unit within the allotted time. Workload can be measured by 3 dimensions, namely time load, mental effort load, and psychological stress load.

\section{Job Characteristics}

Lussier (2014) defines the job characteristics is a model for designing or enriching jobs that focus on the core dimensions of work, the psychological state of employees, and employee needs for growth. Job characteristics can be measured in 5 dimensions, namely skill variety, task identity, task significance, task autonomy, and feedback .

\section{E. Hypothesis}

Based on the problem formulation and literature review, a conceptual framework and hypothesis development can be formulated :

- H1: Workload has a positive and significant effect on employee performance.

An employee's workload can be interpreted as a positive (as a challenge) and negative (as a cause of fatigue that decreases employee performance), depending on the perception of individual receives. Irawati and Carolline (2017) and Rolos, et al (2018) found that workload affects employee performance. In addition, Shah et al (2011) found that workloads can have a positive connotation which leads to improved performance.

- H2: Job characteristics have a positive and significant effect on employee performance.

Ling and Toh (2014); Wood et al., (2012); Zhao and Ghiselli (2016) have recapitulated that good job design can give employees the opportunity to use various skills and talents to perform tasks, associate or identify themselves to complete tasks, feel empowered to do work through the autonomy obtained, and get feedback from their work. Enriched and complex work is associated with positive attitude outcomes. This status determines the performance of an employee at work.H3: Workload has a positive and significant effect on work-school conflict.

- H3: workload has a positive and significant effect on work-school conflict.

The hypothesis formulation is based on research by Palupi (2009) stating that dual role has a positive relationship with workload, which means the higher workload can higher the work-school conflict.

- H4: Job characteristics have a positive and significant effect on work-school conflict.

The results of a study conducted by Carvalho \& Chambel (2017) found that more clearly the job characteristics of employee will affect the high work-family conflict. This is in line with several studies that show the importance of job characteristics as part of WFC and work-family enrichment (Carvalho \& Chambel, 2014; Michel, Kotrba, Mitchelson, Clark, \& Baltes, 2011).

- H5: Work-school conflict has a negative and significant effect on employee performance. According to the results of research by Andrade (2018) WSC is influenced by work schedules, high work demands, and low control of work, so WSC will be inversely proportional to student involvement and academic performance. Supported research conducted by Jackson and Arianto (2017) which states that dual role have no significant and negative effect on the employees performance, as well as Wyland et al (2013) which states that the School-work conflict negatively affect employee performance. 
- H6: Work School Conflict is able to play a role in mediating the effect of workload on employee performance.

Shah, et al (2011) found that workload pressure can be positive and this leads to improved performance. The existence of the application of the workload makes employees are required to release all the potential they have. Supported by research conducted by Rolos et al. (2018) where workload has a negative and significant effect on employee performance. In addition, research by Burhanuddin et al (2018), Jackson and Irianto (2017), and Wyland et al (2013) found that the dual role had a negative effect on employee performance. The results of the study reinforce the negative relationship between workload and employee performance through work-school conflict.

- H7: Work School Conflict is able to play a role in mediating the effect of job characteristics on employee performance

Carvalho \& Chambel (2017) in his research found that job characteristics had a positive and significant effect on work-family conflict. Research conducted by Affandy (2016) found that job characteristics have a positive effect on employee performance, so that, it can be said that a clearer job description for an employee can improve the performance of their workers. Both of these results can strengthen the relationship between job characteristics and employee performance through work-school conflict.

Based on the explanation above, the conceptual framework is formed below

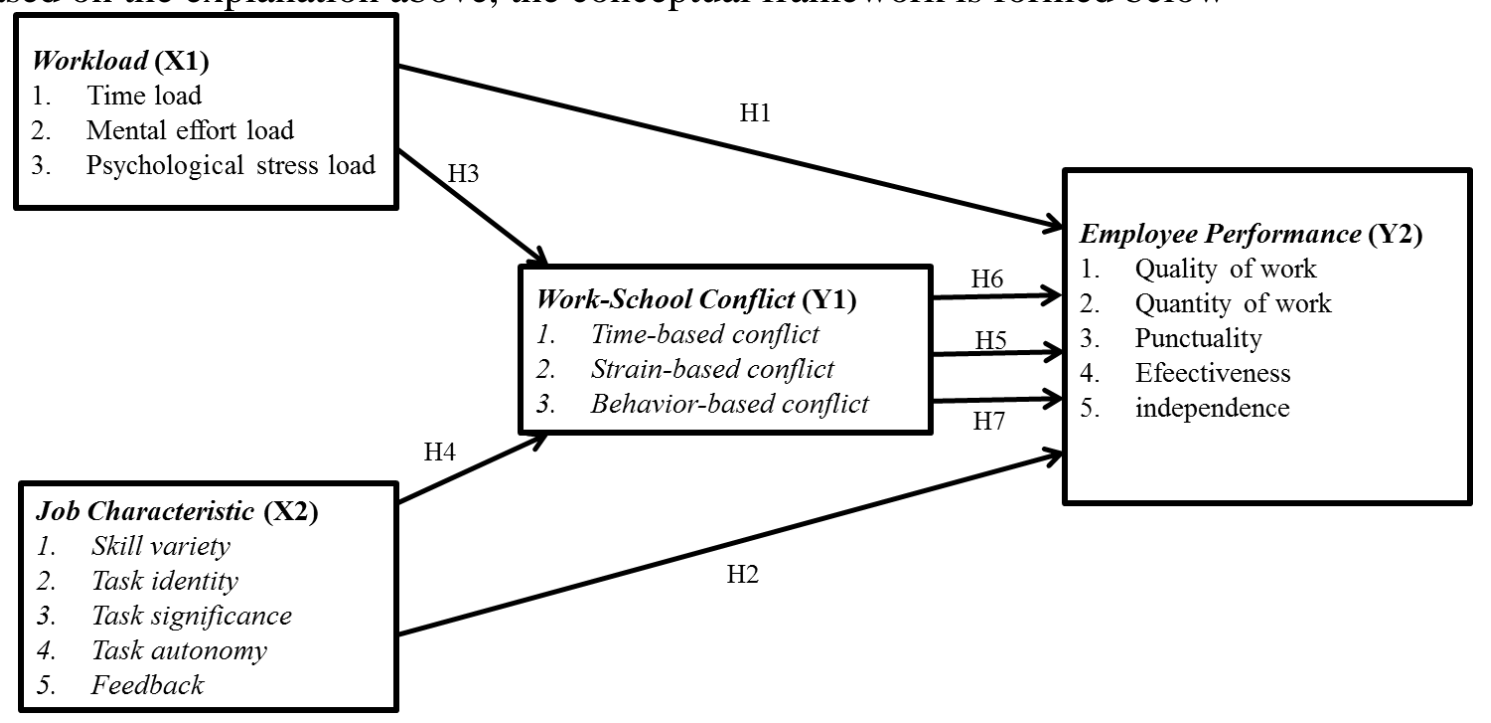

Source: Processed data (2019)

Figure 1. Conceptual Framework

\section{RESEARCH METHODS}

This study uses a quantitative approach with an explanatory design, which is a study that explains the position of the variables studied and the relationship between one variable with other variables (Sekaran \& Bougie, 2017). The study used in this study is a causal study. Causal studies are studies that examine whether one variable causes other variables to change or not (Sekaran \& Bougie, 2017) .

There are three variables used in this study, namely the independent variable, the dependent variable, and the mediating variable. Workload variable (X1) and job characteristics 
(X2) as independent variables. Variable work-school conflict (Y1) as a mediating variable and variable employee performance (Y2) as the dependent variable.

The population in this study are employees who are continuing graduate studies from Universities in the Jakarta that are Accredited A. In this study the total overall indicator is 60, according to which Tabachnick and Fidell (Hair, 1998) approach the sample is obtained by multiplying 5-15 with a number of indicators, namely 300 respondents.

The data collection technique was carried out through the convenience sampling method, in which the researcher distributed questionnaires to respondents who were considered easily found and in accordance with the terms and conditions of the sample. The method of data collection uses a questionnaire instrument with a Likert scale. The data analysis method uses SEM-PLS 3.0 to evaluate outer model and evaluate inner model.

\section{FINDINGS AND DISCUSSION}

\section{Evaluation of the Measurement Model ( Outer Model )}

this measurement was carried out to find out the validity and reliability that connects the dimensions with latent variables. Validity test is done through two methods, namely convergent validity and discriminant validity. The reliability test was carried out through two methods, namely cronbach's alpha and composite reliability. The results of the validity test showed all dimensions of the variables were valid and the reliability showed that each variable was reliable to be used as an instrument in the study.

\section{Validity Test \\ Convergent validity}

Evaluation of convergent validity is seen through the loading factor and average variance extracted (AVE) values. The loading factor value used is $\geq 0.5$, so if the loading factor value < 0,5 , it will be removed from the model. Figure 4.1 shows the loading factor of the dimensions of the variable.

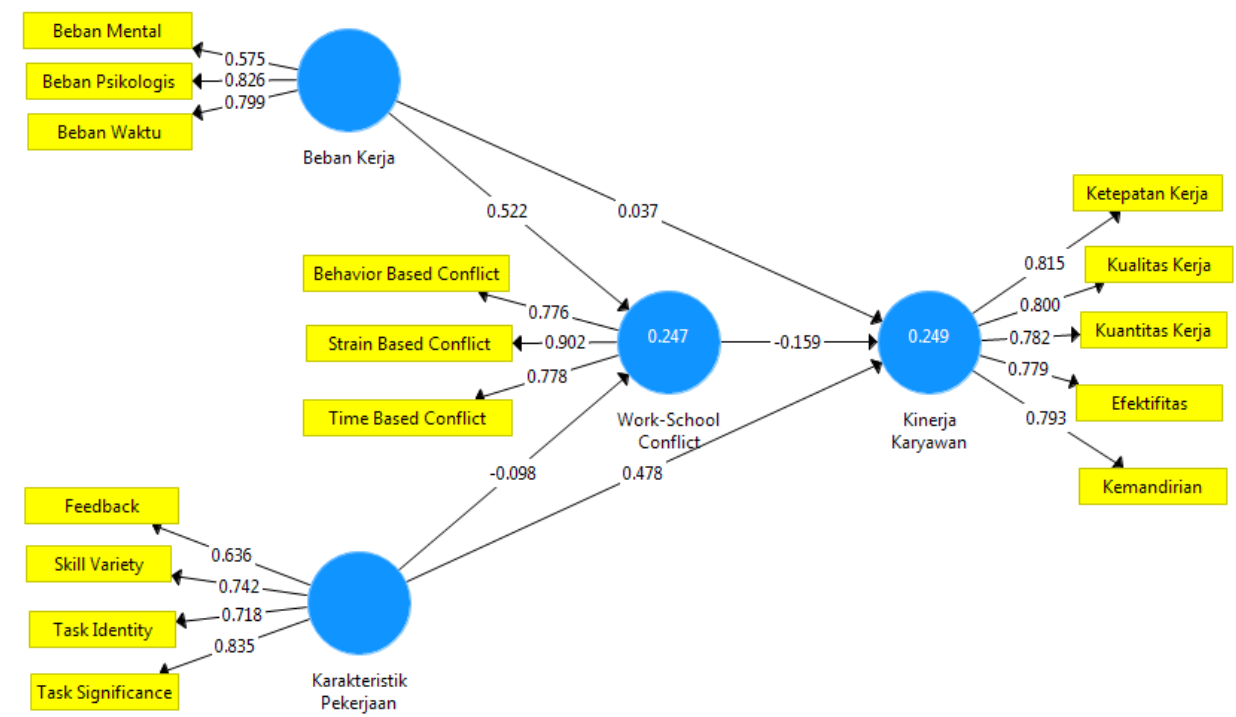

Figure 2. Evaluation of Loading Factor Values

Source: processed by the author (2019)

In addition, the AVE value is also used as an indicator of the assessment. According to Hair et al (2014) the AVE value must be > 0.5, Table 4.1 shows the AVE value: 
Table 4. AVE value

\begin{tabular}{lr}
\hline \multicolumn{1}{c}{ Variable } & AVE value \\
\hline Workload & 0.550 \\
Job Characteristics & 0.542 \\
Work-School Conflict & .674 \\
Employee performance & 0.630 \\
\hline Source: Processed research data (2019)
\end{tabular}

\section{B. Discriminant Validity}

Evaluation of discriminant validity is done by examining the value of cross loading and square root of AVE. Evaluation of the value of cross loading, that is the dimension correlation coefficient value must be greater for the construct compared to other constructs. Table 5 shows the cross loading dimension values for the construct.

Table 5. Discriminant Validity Test Results

\begin{tabular}{lccccc}
\hline \multicolumn{1}{c}{ Indicator } & Workload & $\begin{array}{c}\text { Job } \\
\text { Characteristics }\end{array}$ & $\begin{array}{c}\text { Work- } \\
\text { School } \\
\text { Conflict }\end{array}$ & $\begin{array}{c}\text { Employee } \\
\text { performance }\end{array}$ & Information \\
\hline $\begin{array}{l}\text { Mental effort } \\
\text { load }\end{array}$ & $\mathbf{0 . 5 7 5}$ & 0.373 & 0.195 & 0.221 & Valid \\
\hline $\begin{array}{l}\text { Psychological } \\
\text { stress load }\end{array}$ & $\mathbf{0 . 8 2 6}$ & 0.221 & 0.441 & 0.047 & Valid \\
\hline Time load & $\mathbf{0 . 7 9 9}$ & 0.245 & 0.400 & 0.072 & Valid \\
\hline Skill Variety & 0.275 & $\mathbf{0 . 7 4 2}$ & 0.043 & 0.352 & Valid \\
\hline Task Identity & 0.212 & $\mathbf{0 . 7 1 8}$ & 0.077 & 0.359 & Valid \\
\hline $\begin{array}{l}\text { Task } \\
\text { Significance }\end{array}$ & 0.314 & $\mathbf{0 . 8 3 5}$ & 0.061 & 0.376 & Valid \\
\hline Feedback & 0.218 & $\mathbf{0 . 6 3 6}$ & 0.066 & 0.315 & Valid \\
\hline $\begin{array}{l}\text { Behavior Based } \\
\text { Conflict }\end{array}$ & 0.403 & 0.142 & $\mathbf{0 . 7 7 8}$ & 0.061 & Valid \\
\hline $\begin{array}{l}\text { Strain Based } \\
\text { Conflict }\end{array}$ & 0.458 & 0.082 & $\mathbf{0 . 9 0 2}$ & $-0,110$ & Valid \\
\hline $\begin{array}{l}\text { Time Based } \\
\text { Conflict }\end{array}$ & 0.333 & $-0,018$ & $\mathbf{0 . 7 7 6}$ & $-0,191$ & Valid \\
\hline Quality of Work & 0.116 & 0.401 & $-0,040$ & $\mathbf{0 , 8 0 0}$ & Valid \\
\hline $\begin{array}{l}\text { Quantity of } \\
\text { Work }\end{array}$ & 0.029 & 0.336 & $-0,115$ & $\mathbf{0 . 7 8 2}$ & Valid \\
\hline Punctuality & 0.073 & 0.406 & $-0,112$ & $\mathbf{0 . 8 1 5}$ & Valid \\
\hline Effectiveness & 0.088 & 0.360 & $-0,089$ & $\mathbf{0 . 7 9 3}$ & Valid \\
\hline \begin{tabular}{l} 
Independence \\
\hline Source Processed
\end{tabular} & 0.188 & 0.385 & $-0,046$ & $\mathbf{0 . 7 7 9}$ & Valid \\
\hline
\end{tabular}

Source: Processed research data (2019)

In addition, the AVE root value is also used as an assessment indicator of discriminant validity. Evaluation is done by comparing the value of AVE for each construct with the correlation between other constructs. Table 4.3 shows the value of AVE. 
Table 6. Root of AVE Value

\begin{tabular}{lrrrr}
\hline & Workload & $\begin{array}{c}\text { Job } \\
\text { Characteristics }\end{array}$ & $\begin{array}{l}\text { Employee } \\
\text { performance }\end{array}$ & $\begin{array}{l}\text { Work- } \\
\text { School } \\
\text { Conflict }\end{array}$ \\
Workload & $\mathbf{0 , 7 4 2}$ & & & \\
Job Characteristics & 0,348 & $\mathbf{0 , 7 3 6}$ & & \\
Employee Performanc & 0,125 & 0,478 & $\mathbf{0 , 7 9 4}$ & \\
Work-School Conflict & 0,488 & 0,084 & $-0,101$ & $\mathbf{0 , 8 2 1}$ \\
\hline
\end{tabular}

Source: Processed research data (2019)

Tables 5 and 6 show the value of cross loading and root AVE dimensions in the construct> compared to other constructs.

\section{Reliability Test}

Reliability test is carried out to test the consistency and stability of the items studied. The reliability test consists of two tests, namely Cronbach's alpha and composite reliability which can be seen in Table 7 .

Table 7. Cronbach's Alpha Value and Composite Reliability (CR)

\begin{tabular}{lcc}
\hline \multicolumn{1}{c}{ Variable } & Cronbach's Alpha & Composite Reliability (CR \\
\hline Workload & 0,60 & 0,782 \\
Job Characteristics & 0,71 & 0,824 \\
Work-School Conflict & 0,75 & 0,860 \\
Employee performance & 0,85 & 0,895 \\
\hline
\end{tabular}

Source: Processed research data (2019)

Based on table 7 it can be seen that the Cronbach's alpha value for the variables studied is more than 0.6 and composite reliability is more than 0.7 . So that it can be concluded that all research variables are stated to be reliable.

\section{Evaluation of Structural Model (Inner Model)}

Evaluation of structural models (inner models) conducted through the steps to validate the structural model as a whole with the Goodness of Fit Index (GoF), evaluate the value of $R^{2}$, testing predictive relevance $\left(\mathrm{Q}^{2}\right)$, and hypotheses test through path coefficient.

\section{A. Goodness of Fit (GoF)}

The purpose of testing the Goodness of Fit Index (GoF) is to validate the combined performance of the measurement model ( outer model) and the structural model (inner model ) obtained through calculations as follows:

$$
\begin{aligned}
& \mathrm{GoF}=\sqrt{A V E \times R^{2}} \\
& \mathrm{GoF}=\sqrt{0,599 \times 0,030} \\
& \mathrm{GoF}=\sqrt{0,01797} \\
& \mathrm{GoF}=0,1340 \\
& \mathrm{Information} \mathrm{:} \\
& \mathrm{AVE}=(0,550+0,542+0,674+0,630) / 4=2,396 / 4=0,599
\end{aligned}
$$$$
\text { R square }=(0,247 \times 0,249) / 2=0,030
$$

The calculation results of the Goodness of Fit Index (GoF) showed a value of 0,1340. Based on these results it can be concluded that the combined performance of the measurement model 
(outer model ) and structural model (inner model) as a whole is quite good because the Goodness of Fit Index (GoF) value is more than 0,10 (small scale).

\section{B. R-square $\left(\mathbf{R}^{2}\right)$}

$\mathrm{R}$ square evaluation is used to measure the degree of variation changes in exogenous variables with their endogenous variables. The higher value of $\mathrm{R}^{2}$ means the better research model proposed. To evaluate the value of $\mathrm{R}^{2}$ based on calculations using the calculate SmartPLS version 3.0 with the results of the $\mathrm{R}^{2}$ is 0.247 for the variable work-school conflict and 0.249 for the variable employee performance. The value of $\mathrm{R}^{2}$ indicate that the level of determination of independent variables (workloads and job characteristics) against the dependent is average.

\section{Predictive Relevance $\left(\mathbf{Q}^{2}\right)$}

The purpose of testing the predictive relevance $\left(\mathrm{Q}^{2}\right)$ is to validate the model. The results of the $\mathrm{Q}^{2}$ calculation are as follows:

$\mathrm{Q}^{2}=1-\left(1-\mathrm{R}_{1}^{2}\right)\left(1-\mathrm{R}_{2}^{2}\right)$

$\mathrm{Q}^{2}=1-(1-0,247)(1-0,249)$

$\mathrm{Q}^{2}=1-(0,753)(0,751)$

$\mathrm{Q}^{2}=1-0,565$

$\mathrm{Q}^{2}=0,435$

The results of the predictive relevance $\left(Q^{2}\right)$ calculation show the value of 0.435 . In our model, the endogenous latent variables have predictive value relevance $\left(Q^{2}\right)>0$ (zero) so that the latent exogenous variables correspond as variable explanatory able to predict variables endogennya, ie work-school conflict and employee performance. So it can be proven that this model has good predictive relevance.

\section{Pathway Coefficient Evaluation and Hypothesis Test}

The results calculation of the path coefficient evaluation using SmartPLS version 3.0 are shown in Table 4.5 for direct effects and Table 4.6 for indirect effects : 
Table 8. Direct Effect of Independent Variable on Dependent Variable

\begin{tabular}{|c|c|c|c|c|c|}
\hline & $\begin{array}{c}\text { Original } \\
\text { Samples } \\
\text { (O) }\end{array}$ & $\begin{array}{l}\text { Sample } \\
\text { Mean } \\
\text { (M) }\end{array}$ & $\begin{array}{l}\text { Standard } \\
\text { Deviation } \\
\text { (STDEV) }\end{array}$ & $\begin{array}{l}\text { T Statistics } \\
\text { (STDEV) }\end{array}$ & $\begin{array}{c}P \\
\text { Value }\end{array}$ \\
\hline $\begin{array}{l}\text { Workload (X1) } \rightarrow \text { employee } \\
\text { performance (Y2) }\end{array}$ & 0,037 & 0,035 & 0,069 & 0,528 & 0,598 \\
\hline $\begin{array}{l}\text { Job Characteristics } \\
\text { (X2) } \rightarrow \text { employee performance } \\
\text { (Y2) }\end{array}$ & 0,478 & 0,483 & 0,065 & 7,299 & 0,000 \\
\hline $\begin{array}{l}\text { Workload (X1) } \rightarrow \text { Work-School } \\
\text { School (Y1) }\end{array}$ & 0,522 & 0,527 & 0,046 & 11,451 & 0,000 \\
\hline $\begin{array}{l}\text { Job Characteristics (X2) } \rightarrow \text { Work- } \\
\text { School Conflict (Y1) }\end{array}$ & $-0,098$ & $-0,097$ & 0,058 & 1,698 & 0,090 \\
\hline $\begin{array}{l}\text { Work-School } \\
\text { Conflict }(\mathrm{Y} 1) \rightarrow \text { Employee } \\
\text { Performance (Y2) }\end{array}$ & $-0,159$ & $-0,156$ & 0,072 & 2,213 & 0,027 \\
\hline
\end{tabular}

Source: Processed research data (2019)

Based on Table 8 the results are obtained:

1. Workload has an influence of 0,037 on employee performance $\mathrm{T}_{\text {statisctic }} 0,528<\mathrm{T}_{\text {table }}(1,97)$ and $p$-values 0,598 .

2. Job characteristics have an influence of 0.478 on employee performance with $\mathrm{T}_{\text {statisctic }} 7,299$ $>\mathrm{T}_{\text {table }}(1,97)$ and $p$-values 0,000 .

3. Workload have an influence of 0,522 on work-school conflict with $T_{\text {statisctic }}(11,451)>T_{\text {table }}$ $(1,97)$ and $p$-values 0,000 .

4. Job characteristics have an influence of $-0,098$ on work-school conflict with $\mathrm{T}_{\text {statisctic }} 1,698$ $<\mathrm{T}_{\text {table }}(1,97)$ and $p$-values 0,090 .

5. Work-school conflict have an influence of $-0,159$ on employee performance with $\mathrm{T}_{\text {statisctic }}$ $2,213>\mathrm{T}_{\text {table }}(1,97)$ and $p$-values 0,027 .

Table 9. Indirect Effect of Independent Variable on Dependent Variable

\begin{tabular}{|c|c|c|c|c|c|}
\hline & $\begin{array}{l}\text { Original } \\
\text { Samples } \\
\quad(\text { O) }\end{array}$ & $\begin{array}{l}\text { Sample } \\
\text { Mean } \\
\text { (M) }\end{array}$ & $\begin{array}{l}\text { Standard } \\
\text { Deviation } \\
\text { (STDEV) }\end{array}$ & $\begin{array}{l}\text { T } \\
\text { Statistics } \\
\text { (STDEV) }\end{array}$ & $\begin{array}{c}P \\
\text { Value }\end{array}$ \\
\hline $\begin{array}{l}\text { Workload } \rightarrow \square \text { Work-School } \\
\text { Conflict } \rightarrow \square \text { Employee } \\
\text { Performance }\end{array}$ & $-0,083$ & $-0,082$ & 0,039 & 2,148 & 0,032 \\
\hline $\begin{array}{l}\text { Job Characteristics } \rightarrow \square \text { Work- } \\
\text { School Conflict } \rightarrow \text { Employee } \\
\text { Performance) }\end{array}$ & 0,016 & 0,015 & 0,012 & 1,340 & 0,181 \\
\hline
\end{tabular}

Source: Processed research data (2019)

6. Workload throug work-school conflict have an influence of 0,083 on employee performance with $\mathrm{T}_{\text {statisctic }} 2,148>\mathrm{T}_{\text {table }}(1,97)$ and $p$-values 0,032 .

7. Job characteristics through work-school conflict have an influence of 0,016 on employee performance with $\mathrm{T}_{\text {statisctic }} 1,340<\mathrm{T}_{\text {table }}(1,97)$ and $p$-values 0,181 . 
T-table values obtained from $(\mathrm{df}=300-4)$ alpha $0.005=1.97$

The bootstrapping calculation results of the research model can be seen in Figure 4.2

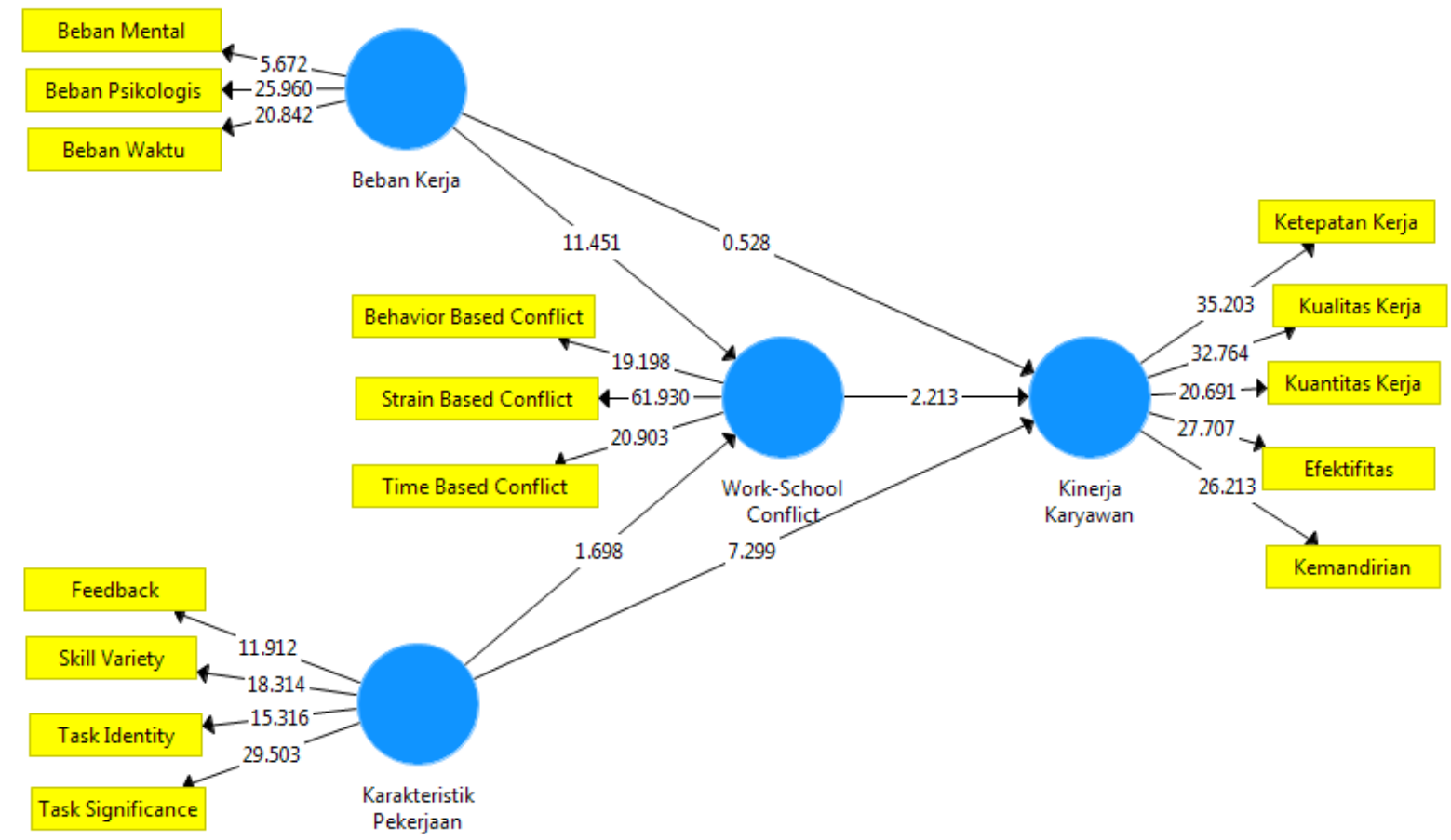

Figure 3. Bootstrapping Calculation Results with Mediation Variables

Source: processed by the author (2019)

\section{Hypothesis 1: effect of workload in employee performance}

The $p$-value of workload variable (X1) on employee performance variable (Y2) of 0.598 with a $\mathrm{T}_{\text {statistic }}$ of $0.528<\mathrm{T}_{\text {table }}(1.97)$ and the original sample is positive, then $\mathbf{H}_{1}$ was rejected and it is concluded that the workload variable (X1) has no effect and not significant to employee performance variables (Y2), thus the higher workload perceived by employees does not affect work performance.

This is in line with the study of Murali et al (2017) which concluded that workload does not significantly influence employee performance. There is nothing an employee can do to avoid the workload given, whether or not the employee in his work still has to take on any workload. While research conducted by Irawati and Carolline (2017) explains that internal workload has a positive effect and external workload has a negative effect on employee performance, as well as research conducted by Rohmah (2017) which concludes that workload has a positive and significant effect on employee performance.

\section{Hypothesis 2: Pengaruh Karakteristik Pekerjaan terhadap Kinerja Karyawan}

The $p$-value of job characteristics variable (X2) on employee performance variables (Y2) of 0,000 with a $\mathrm{T}_{\text {statistic }}$ of $7.299>\mathrm{T}_{\text {table }}(1.97)$ and the original sample were positive, then $H_{2}$ was accepted and concluded that the employee characteristic variable (X2) had a positive effect and significant to employee performance variables (Y2), thus the relationship of job characteristics plays an important role in influencing employee performance, the clearer the job design that is described in the five core dimensions of job characteristics, the employee's performance will increase.

This is in line with research by Affandy (2016), Chandra et al (2011), and Kassem and 
Sarhan (2013) which states that job characteristics have a positive and significant effect on employee performance. This proves that the results of this study are consistent and support previous research. In addition, Evelyn et al (2018) in their research concluded that skill variety, task identity, task autonomy, and feedback had positive and significant effects on employee performance, while task significance had a positive and not significant effect on employee performance.

\section{Hypothesis 3: Effect of workload on Work-School Conflict}

The $p$-value of workload variable (X1) on work-school conflict variable (Y1) of 0,000 with $\mathrm{T}_{\text {statistic }}$ of 11.451> $\mathrm{T}_{\text {table }}$ (1.97) and the original sample is positive, then $\mathbf{H}_{3}$ was accepted and concluded that the workload variable (X1) has an effect positive and significant towards the work-school conflict variable (Y1), thus the higher the workload, the higher the perceived employee-student conflict.

This is in line with research conducted by Laughman et al (2016) which concluded that workload has a positive and significant effect on work-school conflict, which means that the higher the workload, the higher the perceived conflict. Whereas research conducted by Andrade (2018) concluded that workload did not significantly influence work-school conflict.

\section{Hypothesis 4: effect of job characteristics on Work-School Conflict}

The $p$-value of job characteristics variable (X2) on the work-school conflict variable (Y1) of 0.090 with a $\mathrm{T}_{\text {Statistic }}$ of $1.698<\mathrm{T}_{\text {table }}(1.97)$ and the original sample is negative, then $\mathrm{H}_{4}$ was rejected and it is concluded that the employee characteristic variable (X2) is not influential and not significant to the work-school conflict variable (Y1), thus the job design created with the aim of describing the five core dimensions of work characteristics does not affect the work-school conflict felt by student-employees.

This is not in line with research conducted by Butler (2007) which states that work characteristics have a positive effect on work-school conflict (WSC), specifically it is shown that more work hours and work demands can be associated with increased work-school conflict.

\section{Hypothesis 5: Effect Work-School Conflict on Employee Performance}

The $p$-value of work-school conflict variable (Y1) on employee performance variables (Y2) of 0.027 with a $\mathrm{T}_{\text {Statistic }}$ of 2.213> $\mathrm{T}_{\text {table }}(1.97)$ and the original sample were negative, then H5 was accepted and concluded that the work-school conflict variable (Y1) negative and significant effect on employee performance variables (Y2), thus the higher the conflict felt by employee-student resulting in decreased employee performance.

This is in line with research conducted by Wyland (2013) which states that work-school conflict negatively affects employee performance that contains job dedication, interpersonal facilities, and task performance. In addition, the study of Buhanuddin et al (2018) concluded that dual role conflict had a negative and not significant effect on employee performance.

\section{Hypothesis 6: Work-School Conflict able to Mediating the Effect of Workload on Employee Performance}

The results of testing the hypothesis by including and without including work-school conflict variables as mediating variables in the effect of workload on employee performance are presented in Figure 4.

1) Path $\mathrm{a}=$ Workload has a positive and significant effect on work-school conflict.

2) Path $b=$ Work-school conflict has a negative and significant effect on employee performance. 
3) Path $\mathrm{c}=$ The direct effect of workload on employee performance by involving work-school conflict variables results in a negative and significant effect

4) Path $\mathrm{d}=$ Direct effect of workload on employee performance without involving workschool conflict variables getting no effect.

That is, the nature of work-school conflict mediation in the relationship of workload to employee performance is full mediation. It can be concluded that $\mathrm{H}_{6}$ was accepted.
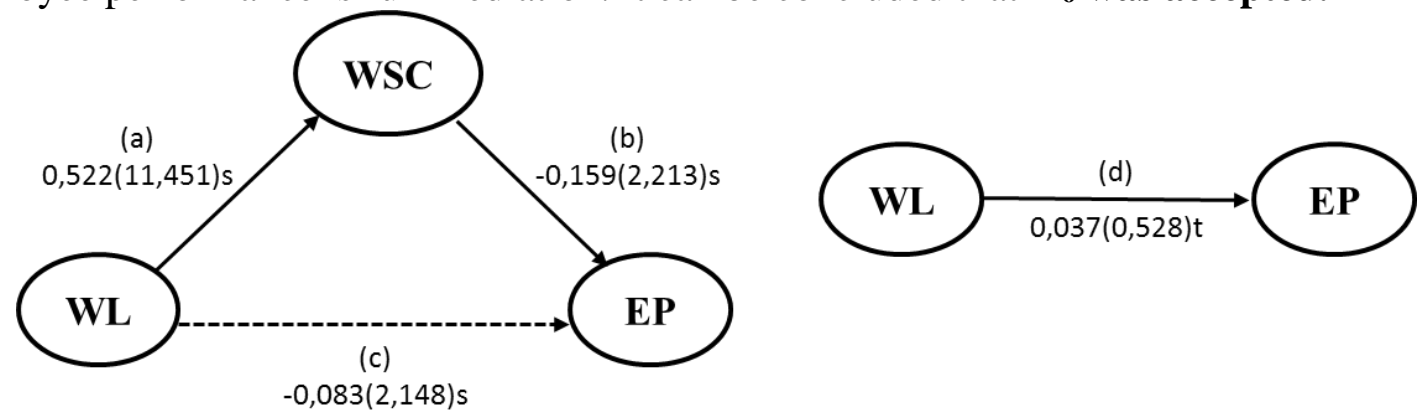

Figure 4. Work-School Conflict Testing Results as a Mediation Variable

Source: processed by the author (2019)

Information:

* The number that is located on each path shows the value of the path coefficient and the enclosed shows the $t$ - value .

$\mathrm{s}=$ significant at the 0.05 level

$\mathrm{t}=$ not significant

WSC $=$ Work-School Conflict

$\mathrm{WL}=$ Workload

$\mathrm{EP}=$ Employee Performance

\section{Hypothesis 7: Work-School Conflict able to Mediating the Effect of Job Characteristics on Employee Performance}

The results of testing the hypothesis by including and without including work-school conflict variables as mediating variables in the effect of workload on employee performance are presented in Figure 5.

1) Path $\mathrm{a}=$ Job characteristics have no effect on work-school conflict

2) Path $b=$ Work-school conflict has a negative and significant effect on employee performance.

3) Path $\mathrm{c}=$ direct effect of job characteristics on employee performance by involving work-school conflict variables getting no effect.

4) Path $\mathrm{d}=$ direct effect of job characteristics on employee performance without involving work-school conflict variables get positive and significant effect.

That is, the nature of work-school conflict mediation in the relationship of job characteristics to employee performance is not to mediate the relationship between the two variables. So it can be disimpulk late that $\mathbf{H 7}$ was rejected. 

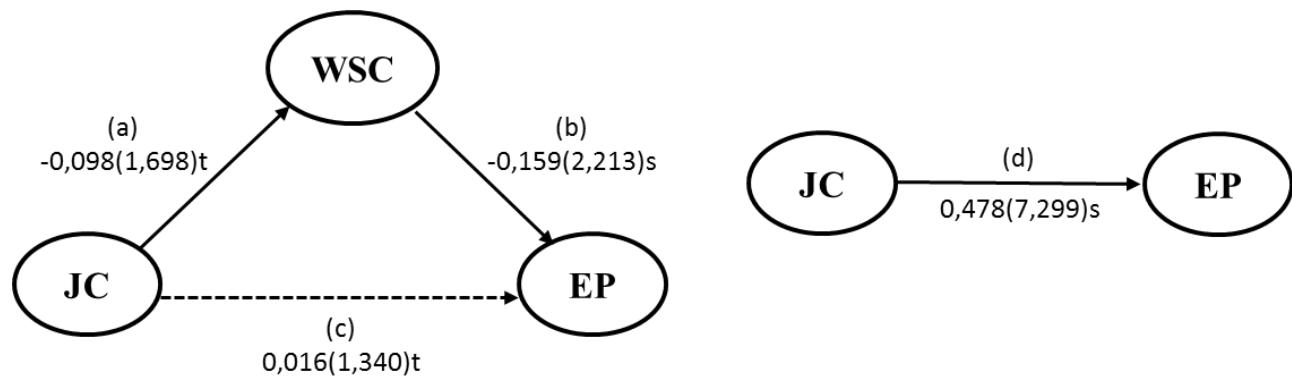

Figure 5. Work-School Conflict Testing Results as a Mediation Variable

Source: processed by the author (2019)

Information:

* The number that is located on each path shows the value of the path coefficient and the enclosed shows the t- value .

$\mathrm{s}=$ significant at the 0.05 level

$\mathrm{t}=$ not significant

WSC $=$ Work-School Conflict

$\mathrm{JC}=\mathrm{Job}$ Characteristics

$\mathrm{EP}=$ Employee Performance

\section{CONCLUSION AND SUGGESTION}

\section{Conclusion}

1) Workload does not affect employee performance, with the dimensions of psychological stress load as the most instrumental dimension unable to influence employee performance.

2) Job Characteristics has a positive and significant effect on employee performance, with a dimension of task significance into the dimension most instrumental in influencing the performance of employees.

3) Workload have positive and significant effect on work-school conflict. The higher workload will perceived the higher conflict. The dimensions of the psychological stress load play the most role in influencing work-school conflict.

4) Job characteristics does not significantly influence the work-school conflict, with dimensions of task significance as the most instrumental dimension is not able to influence the work-school conflict.

5) Work-school conflict have negative and significant effect on the employee performance with strain-based conflict dimension into a most instrumental dimension in influencing the employees performance.

6) Work-school conflict could play a role to full mediate workload on employee performance, it means work-school conflict can increase the relationship between workload and employee performance.

7) Work-school conflict has no mediated role of the job characteristic on employee performance.

\section{Suggestion}

\section{For Company}

a) Work mapping needs to be done to employees related to the workload being borne, so that work is not concentrated on certain employees only.

b) Time -based conflict becomes a dimension that correlates significantly to employee performance so that several things need to be done to reduce perceived conflicts so that employee performance can be improved and academic performance also remains good, 
such as making a clear job mapping and providing specific policies for employees who are in college, for example are allowed to go home early.

c) Skill variety and task significance become dimensions that have a significant correlation to employee performance, so several things need to be done to improve it. Skill variety can be increased by providing training, while task significance can be increased by making job evaluations in every position in the company and providing understanding and information about the company's business processes.

\section{For University}

University can also improve the online-based service system so that both HR and the facilities and infrastructure will be more efficient. One of the aspects that can be developed is the registration of the final project (Thesis) which is done online.

\section{For Further Researches}

a) Look for other mediating variables related to workload and job characteristics on employee performance, such as perceived organizational support, job satisfaction, and work motivation.

b) Further research is needed with respondents included in structural positions (at least the Head of Department) to see the effect of job autonomy on the variable job characteristics.

\section{REFERENCE}

Affandy, Rizal Eka. (2016). "Pengaruh Karaktertistik Pekerjaan Terhadap Kinerja Pegawai dengan Motivasi dan Lingkungan Kerja sebagai Varabel Pemoderasi”. Ekonomika-Bisnis. Vol 07, No. 02. 77-86.

Andrade, Claudia. (2018). "Professional work load and work-to-school conflict in workingstudents: The mediating role of psychological detachment from work". Psychology, Society, \& Education. Vol. 10(2), 215-224.

Burhanuddin, Trisna Dewi, herman Sjahruddin, Abd. mansyur Mus. (2018). "Pengaruh Konflik Peran Ganda terhadap Kinerja Melalui Stres Kerja". Jurnal Organisasi dan Manajemen, Issue 1, 1-18.

Carvalho, V. S., \& Chambel, M. J. (2014). "Work-to-family enrichment and employees' wellbeing: High performance work system and job characteristics". Social Indicators Research, 119, 373-387.

Frismandiri, Dinda. (2007). "Analisis Pengaruh Karakteristik Pekerjaan, Kepuasan Kerja, dan Komitmen terhadap Kinerja Karyawan". Jurnal Ekonomi Modernisasi. Vol. 3, No. 2. 114-134.

Hair, J. F., Black, W. C., Babin, B. J., \& Anderson, R. E. (1998). Multivariate Data Analysis. New York: Prentice Hall International.

Hair, J. F., Hult, G. T., Ringle, C. M., \& Sarstedt, M. (2014). A Primer on Partial Least Squares Structural Eqution Modelin (PLS-SEM). United States: SAGE Publication, Inc.

Irawati, Rusda, Dini Arimbi Carollina. (2017). "Analisis Pengaruh Beban Kerja terhadap Kinerja Karyawan Operator pada PT Giken Precision Indonesia". Jurnal Inovasi dan Bisnis. Vol. 5. No. 1. 53-58. 
Jackson dan Yohanes Arianto. (2017). "Pengaruh work school conflict terhadap Kinerja Karyawati PT Sinta Pertiwi". Jurnal Kreatif: Pemasaran, Sumber Daya Manusia, dan Keuangan. Vol. 5, No. 1.99-111.

Lussier, R. N. (2009). Management Fundamentals: Concepts, Applications Skill Development. $6^{\text {th }}$ Ed. Cengage Learning. South Western.

Michel, J. S., Kotrba, L. M., Mitchelson, J. K., Clark, M. A., \& Baltes, B. B. (2011). "Antecedents of work-family conflict: A meta-analytic review". Journal of Organizational Behavior, 32, 689-725.

Park, Y., dan Sprung, J. M. (2013). "Work-School Conflict and Health Outcome: Beneficial Resources for Working College Students". Journal of Occupational Health Psychology, Vol 18. 384-394.

Rolos, Jeky K. R., Sofia A. P. Sambul, Wehelmina Rumawas. (2018). "Pengaruh beban kerja terhadap kinerja karyawan pada PT. Asuransi Jiwasraya Cabang Manado Kota". Jurnal Administrasi Bisnis. Vol. 6, No. 4. 19-27.

Sekaran, U., \& Bougie, R. (2017). Metode Penelitian untuk Bisnis. Jakarta Selatan: Salemba Empat.

Shah, S. H. (2011). "Workload and performance of employee". Interdisciplinary Journal of Contemporary Research in Business. Vol. 3 No. 5. 